\title{
Contributions to the taxonomy and ecology of the Chironomus plumosus sibling species aggregate (Diptera: Chironomidae): the brackish water populations of Tvärminne area, Finland
}

\author{
Mauri Hirvenoja
}

Hirvenoja, M. 2006: Contributions to the taxonomy and ecology of the Chironomus plumosus sibling species aggregate (Diptera: Chironomidae): the brackish water populations of Tvärminne area, Finland - Entomol. Fennica 17: 373380 .

Based on pupal exuviae, two sympatric pupal forms of Chironomus plumosus auctt. are present in the museum materials collected in 1952-1962 from the brackish water near the Tvärminne Biological Station at the northern Baltic Sea. The predominating undescribed type of the pupal exuviae is called here the "Baltic marine species" (possible C. plumosus sensu Linnaeus; direct observations by Linnaeus of Tipula plumosa from freshwater are not on record). Its pupal exuviae and the associated female and male from the Tvärminne population are described. Attempts to find larvae of the genus Chironomus in the sea area of Tvärminne for the renewed and more complete studies failed during the 1980s and 1990s. Only two larvae of the undescribed species of the karyological Chironomus plumosus group were captured. The possible reasons for the supposedly changed environmental conditions are discussed.

\section{Hirvenoja, Sotilaskorventie 13, FI-01730 Vantaa, Finland}

Received 20 January 2004, accepted 22 November 2005

\section{Introduction}

Over ten defined sibling species have been described in a group which should include, among others, Chironomus plumosus (Linnaeus), some only on the basis of the larval karyology. Many of them may be sympatric, but the morphological determination in different sites may be difficult e.g. because of intraspecific variation. In the list of Michailova (2001) there are three species that have been karyologically recorded from Finland.

In the morphological sibling species aggregate of Chironomus plumosus (as treated in the present paper), the pale adults are quite similar to each other. The BR (beard ratio) value (Strenzke 1959) of the adult male fore tarsi is high. The pupal exuviae have patches of about $10 \mu \mathrm{m}$ long and proximally $1-2 \mu \mathrm{m}$ thick spinules in the anal corners of segments 5-7, which are a little strengthened obviously synapomorphously, whereas paratergites 5-8 are smooth as in some other species of this genus.

This combination of characters appears to be present also in the pupae of C. nuditarsis Keyl, the males of which are easily separable from the species of the aggregate discussed here by the short BR value. Also the pupae of the more plesiomorphous species C. coaetaneus Hirvenoja 
(that has a very dark adult) are quite similar with the species of the aggregate.

Taxonomical differentiation of sibling species is important in the biological monitoring of the environment. If no separation is achieved, the unresolved "collective species" can appear as ubiquitous, which significantly reduces the relevance of such studies. A great mass of limnological information has been published under the name Chironomus plumosus (L.), unfortunately often at a taxonomic level that precludes referring to such data with confidence.

It is not necessary to use terms such as the "plumosus group", "plumosus type" larvae (ventral tubules at least as long as the corresponding segment, lateral tubules of segment 7 present), or "semireductus type", etc., and they should be discontinued. This is especially true for the lastmentioned name, because "semireductus" is not an available scientific name for a species or subspecies. Thienemann (1954: 135-143) discusses earlier studies with particular emphasis on the length of the tubules being species-specific but depending on the oxygen content of the milieu. However, according to Shobanov (1989: 336), there is intraspecific variability in the length of the tubules.

\section{Tipula plumosa Linnaeus (1758)}

Tipula plumosa Linnaeus (1758) was first observed on and near Öland, Sweden and near Kämpinge on the southern Swedish coast [Linnaeus (1745), translated by Åsberg \& Stearn (1973); Linnaeus (1746, 1751, 1758, 1761)]. According to Linnaeus' descriptions the larvae were living mostly in the sea [Linnaeus (1746, 1761): "Habitat hujus Larva in mari”; Linnaeus (1758): "Habitat in Europa, imprimis in maritimis"]. The qualifier "imprimis" (mostly) in the latter statement probably accommodates the descriptions of specimens from inland waters by other authors (e.g. Goedart, Réaumur), which Linnaeus cited and thought to denote the same species. Direct observations by Linnaeus of T. plumosa from freshwater are not on record.

The Linnaean insect collections at the Linnean Society of London reportedly contain one pin-labeled "plumosa" (supposedly by Linnaeus himself), and two more unlabeled pins filed under Tipula plumosa Linnaeus. Unfortunately, no publications (observations or interpretations) of this material are known. As long as the above-mentioned probable type material has not been evaluated, the name Chironomus plumosus (Linnaeus) cannot be used or diagnosed against with any certainty.

This also concerns the relations between the karyologically described species and the numerous synonyms of $C$. plumosus given e.g. by Goetghebuer (1937-1954), because type materials for some names are present in various museum collections (Coll. Meigen, Paris; Coll. Zetterstedt, Lund).

The pupal exuviae of $C$. plumosus sensu Strenzke (1959) and Keyl \& Keyl (1959) have been described by Langton (1991, 1995; cf. Shobanov 2003). This species, which should have smooth $3^{\text {rd }}$ and $4^{\text {th }}$ abdominal sternites, has been karyologically observed especially in several fresh water habitats in Europe. On the basis of the karyology, the same species has also been reported from lakes in Finland [Sodankylä: Lokka reservoir, Inkoo: Marssjön, Lohja: Lohjanjärvi, Anttola: Paljavesi, Savonlinna: Pihlajavesi (Michailova 2001, Michailova \& Mettinen 2000) and one minor variety of exuviae from Lokka, sub Chironomus pr. plumosus Linnaeus illustrated in Hirvenoja (1998)].

On the basis of the pupal exuviae, this common "lacustrine species" (C. plumosus auctt.) occurred like many other freshwater chironomid species in the shallow brackish waters (salinity up to $6 \%$ ) of the Baltic Sea at Tvärminne (Palmén 1955, Palmén \& Aho 1966). Kerkis et al. (1989) used larval karyology and showed a species under the name C. plumosus to occur in Kurshsk Bay, Lithuania, where the salinity according to Järvekülg (1979) is 5-6\%. The pupal exuviae of the last mentioned population are unknown.

In the collection of the Finnish Museum of Natural History, Helsinki, there is one vial containing pupal exuviae similar to that of the most common "lacustrine plumosus" (C. plumosus auctt.) from the shallow alfa-mesohaline (salinity $<2 \%$ ) Gennarbyviken Bay of the Baltic Sea, not far from Tvärminne, collected in July, 1957 by Dr. K. Purasjoki. In exuviae of a single pupa of this sample, traces of spinulation on sternite 3 are 


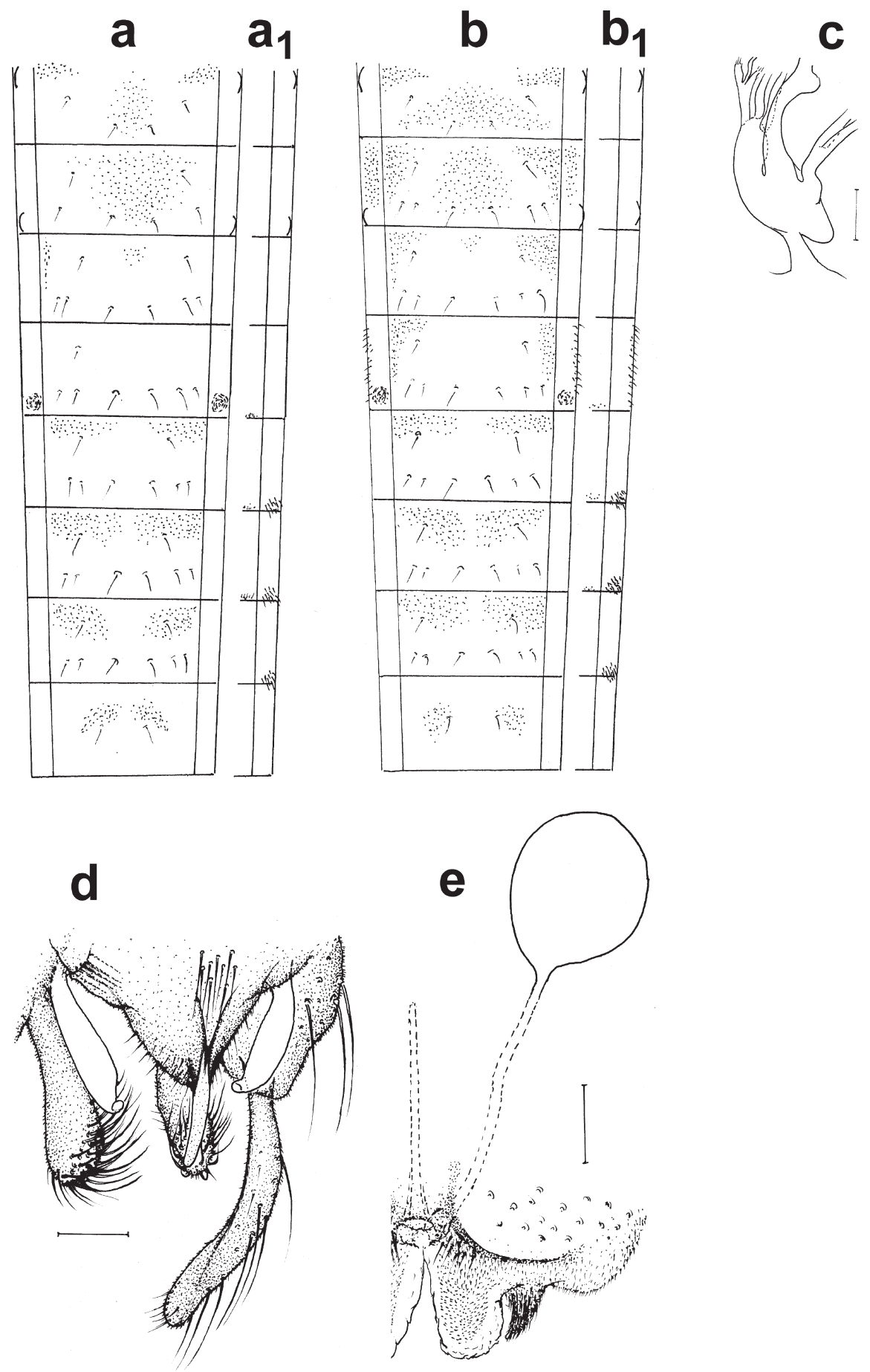

Fig. 1. Chironomus plumosus sibling species aggregate; scale bar $100 \mu \mathrm{m} .-\mathrm{a}$. Variation of the spinulation of abdominal sternites $(a)$, parasternites $(a)$ and paratergites $\left(a_{1}\right)$ schematically in the pupal exuviae of the "lacustrine form". The left side in $(a)=$ the shagreen of an "intermediate individual" from Gennarbyviken. $-b-d$. Details of the "Baltic marine species" from Tvärminne. Spinulation of the sternites $(b)$, parasternites $(b)$ and paratergites $\left(b_{1}\right)$, posterior thoracic tracheal bladder (c), male hypopygium (d), spermatheca and the bilobed subgenitalplate of segment 8 in female. 
also present (Fig. 1a), but the pleural points of segment 4 are absent as is usual in the 'lacustrine plumosus' of the other populations known from the Finnish lakes.

In the population of the Lake Marssjön, Inkoo, ca. $2 \mathrm{~km}$ from the coast of the Gulf of Finland, however, the pleural points of segment 4 are very distinct as in the "Baltic marine species". Karyologically (Michailova 2001) the latter population should also be C. plumosus auctt., i.e. the species called 'lacustrine plumosus' here.

In the literature, there are at least two more karyological species in the C. plumosus aggregate with smooth sternites 3 and 4 (based on material in coll. P. Michailova), namely $C$. bonus Shilova \& Dyvarsheishvili and C. vancouveri Michailova \& Fischer. These have not been found in Finland. In contrast to the most European lacustrine populations, the pupae in the original material of the latter species have pleural points on segment 4 like in the population of Marssjön mentioned before.

Michailova (2001: 105, sub C. plumosus) discusses the peculiarities of the karyology in the population from the brackish water of the Vanhankaupunginlahti bay, Helsinki. In contrast to the lacustrine populations under this name, in the Helsinki population the abundantly spinulated sternites 3 and 4 resemble the type of shagreen of C. balatonicus Dévai, Wülker \& Scholl (in comparison to the specimens from the Lake Balaton in Coll. Michailova).

The pupal exuviae are important for the determination of the species indeed, but every population observed in Finland shows at least some minor unique characters. Unfortunately, as mentioned above, the distinct morphological differences that seem to be available for distinguishing between the "karyological species" seem to disappear between some other allopatric populations. The taxonomical significance of the morphological characters used in the present and in the papers of other authors is therefore somewhat unclear.

Further studies are needed to understand the results found in the karyological and morphological studies. It might be useful always to describe also the morphology of the pupal exuviae when discussing species of the relatives of C. plumosus (cf. Pedersen 1988).

\subsection{Description of the material from the Tvärminne sea area}

Palmén \& Aho (1966) reported the distribution and emergence of a population under the name Chironomus plumosus L. (coll.) in the northern Baltic Sea around the Tvärminne Biological Station. From their measurements of 20 male specimens, the authors concluded that the material captured in Tvärminne agrees quite well with the redescription of this species from the fresh waters of Holstein, Germany by Strenzke (1959). The populations from Holstein were karyologically studied by Keyl \& Keyl (1959). However, although the karyology was not studied in Tvärminne, the difficulties associated with the taxonomy were already well known at that time. This is why the species name was somewhat questioned, as indicated by the expression "(coll.)".

The material from Brännskär was originally composed of 72 individuals [compare tables 16 and 17 in Palmén \& Aho (1966)] that were partly preserved in alcohol and signed by Leena Ahtiainen (= Leena Aho); the material is currently housed in the Finnish Museum of Natural History, Helsinki. If the morphological differences found are of taxonomical importance, this material contains two sympatric sibling species (based on the pupal exuviae) as follows. First, about $20 \%$ of the pupal exuviae from the material (studied in temporary glycerol slides) were similar to the "lacustrine populations" (C. plumosus auctt.) discussed above, i.e. without spinules on the sternites 3 and 4 and without pleural points on segment 4 . Second, about $50-60 \%$ of the exuviae were clearly different, having lateral rows of spinules on sternites 3 and 4 and pleural points on segment 4 (Fig. 1b); this type is called the "Baltic marine population" here.

The condition of many exuviae in the sample was bad and they were difficult to study with certainty. A number of the exuviae (about 20\%) had a variable small number of spinules at least on sternite 4. It was sometimes impossible to observe the pleural points of segment 4 with certainty. In the same collection, under the name $C$. plumosus there is also one vial of pupal exuviae preserved in alcohol and labeled "merestä" (= from the sea) 1952 by E. Palmén. All these exuviae are here understood to be conspecific 
with the exuviae of the "Baltic marine type" collected in Brännskär Bay by Palmén \& Aho (1966).

Many of the original daily samples from the funnel traps were combined every two weeks into one vial by the authors Palmén and Aho. It has been difficult to select from the samples of alcohol-soaked pale adults which adults could be matched with the easily differentiable pupal exuviae in such samples. Therefore it is only possible to describe a single male and two females.

The abundant material from the numerous sites studied by Palmén since 1952 [mentioned in Palmén \& Aho (1966), tables 13-17] has not been found in the Finnish Museum of Natural History.

\subsection{Descriptions of the metamorphosis stages of the "Baltic marine species" from Tvärminne}

\subsubsection{The pupal exuviae}

Detailed measurements are from two exuviae "from the sea, 1952" E. Palmén leg. and two exuviae from the Bay of Brännskär, June-July 1960, Leena Ahtiainen (Aho) leg. (Palmén \& Aho 1966). The drawing of the schematic spinulation (Fig. 1b) is based on about 30 specimen (in temporary glycerol slides).

The exuviae are 16-17 mm long; the thorax is anteriorly and dorsally somewhat darkened. The cephalic tubercles are about $300 \mu \mathrm{m}$ long; the basal rings oval, 240-290 $\mu \mathrm{m}$ long. The posterior thoracic tracheal bladder is as in Fig. 1c.

The shagreen on the tergites is (typically for the genus) quite continuous on the areas where it is present. The paratergites are smooth, but on the posterior corners of segments 5-7 distinct patches of spinules are present (compare Fig. 1a with $1 b_{1}$ ). The hook row on segment 2 comprises 76-103 hooklets, the medial ones have minute dorsal denticles; other intersegmental utmost minute, orally directed spinules are present behind the armament of tergites 4-6. On segment 4, apparently always some thin, $<10 \mu \mathrm{m}$ long pleural points as well as Pedes spurii A are present.

The parasternites 2 are partly spinulated, the other parasternites are smooth. Antero-lateral and median groups of spinules are present on sternites 1 and 2 , but the areas around setae $V_{1}$ are smooth. On sternites 3 and 4, antero-lateral longitudinal groups of spinules are present, as well as, often, traces of median spinules on sternite 3 (Fig. 1b). On sternites 5-7, the antero-lateral patches spread medially, but are not completely fused. Patches of spinules are also present on both sides of sternite 8 near its ventro-median setae.

Lateral setae on segments 1-8: 0,3,3,3, (and taeniated) $3,4,4,4$. There are up to 20 narrow teeth on each anal comb spur of segment 8 . Anal lobe with 2 dorsal taeniae on each side, the lateral multiserial fringe with 186-219 taeniae.

\subsubsection{Adult male}

One emerged male associated with its pupal exuviae (alone in a vial) is available from the Bay of Brännskär, collected 20-23 June, 1960 with a funnel trap by Leena Ahtiainen (Aho). This is a pale individual without pigment between the (in alcohol) brownish scutal stripes. AR 5.8; total

Table 1. Leg segment lengths ( $P 1-P 3$; in $\mu \mathrm{m})$ for males and females.

\begin{tabular}{lrrrrrrr}
\hline & \multicolumn{3}{c}{ Male } & & \multicolumn{3}{c}{ Female } \\
\cline { 2 - 3 } \cline { 6 - 8 } Leg part & P1 & P2 & P3 & & P1 & P2 & P3 \\
\hline Femur & 2,100 & 2,200 & 2,800 & & $1,960-2,290$ & $2,200-2,370$ & $2,650-2,730$ \\
Tibia & 2,200 & 2,300 & 2,800 & & $2,060-2,290$ & $2,270-2,390$ & $2,880-2,730$ \\
Tarsus 1 & - & 1,300 & 1,900 & & $2,490-2,650$ & $1,220-1,310$ & $1,900-1,980$ \\
Tarsus 2 & - & 900 & 1,200 & & $1,450-1,080$ & $800-860$ & $1,100-1,140$ \\
Tarsus 3 & - & 600 & 900 & & $900-900$ & $530-550$ & $840-820$ \\
Tarsus 4 & - & 450 & 550 & & $820-900$ & $370-370$ & $490-570$ \\
Tarsus 5 & - & 300 & 300 & & $410-410$ & $240-330$ & $310-370$ \\
\hline
\end{tabular}


length of the 12th antennal segment $2.1 \mathrm{~mm}$. Frontal tubercle length $60 \mu \mathrm{m}$. Palps normal. Wing lengths $6.3 \mathrm{~mm}$. LR: P1 -, P2 0.57, P3 0.68. Number of sensilla chaetica (distally on) P2/Ta1 $<43, \mathrm{P} 3 / \mathrm{Ta} 1<32$. (Because of the lacking fore tarsi the BR value is not available, but beard setae are long in the entire mixed material.) For the lengths of leg segments P1-P3, see Table 1; the hypopygium is shown in Fig. 1d.

\subsubsection{Adult female}

There are two females associated with the pupal exuviae (in one vial), emerged in a funnel trap, from the Bay of Brännskär, collected in June, 1960 by Leena Ahtiainen (Aho). Frontal tubercle length $40 \mu \mathrm{m}$. Palps normal. Wing length $5.7 \mathrm{~mm}$. LR: P1 1.22-1.25, P2 0.54-0.55, P3 0.67-0.72; BR: P1 1.2-1.3, P2 1.8-2.1, P3 2.1-3.3. Number of sensilla chaetica P2/Ta1 72-133, P3/Ta1 104144. For leg segment lengths, see Table 1.

The spermathecae oval, about $180 \mu \mathrm{m}$ long; both subgenital plates of segment 8 are bilobed, their lateral parts are coarsely haired (Fig. 1e).

Note that the morphological differences between the two "forms" found in Tvärminne may only be seen in the pupal exuviae. In comparison to other known pupae of the C. plumosus aggregate with spinulated abdominal sternites 3 and 4 , the spinulation is broader in C. balatonicus, and in $C$. entis a median shagreen is also present in sternite 3 in the original material of Shobanov and in the material from Finland (Hirvenoja 1998).

\section{Chironomus fauna and water quality at Tvärminne}

Attempts to sample fresh larvae in Tvärminne during various trips in the 1980's and 1990's were not successful. In 1995 only two larvae of a new species belonging to the "karyological plumosus group" and two Camptochironomus were found and studied karyologically by P. Michailova (pers. comm.).

The abundance of the genus Chironomus in the surroundings of the Biological Station seems to have decreased during the past decades. Evidence for this trend can be found in comparison with the total emergence found by Palmén \& Aho
Table 2. Results of measurements by the Tvärminne Biological Laboratory of the variation of water chemistry at depths $1-30 \mathrm{~m}$ in January-December 1998 in the sea area of Storfjärden, an area between the Finnish mainland and the island of Brännskär.

$\begin{array}{ll}\text { Salinity }(\%) & 5.1-6.3 \\ \mathrm{pH} & 7.87-8.49 \\ \mathrm{Chlorophyll} \mathrm{a}(\mu \mathrm{g} / \mathrm{l}) & 0.50-29.40 \\ \mathrm{NH}_{4}(\mu \mathrm{g} / \mathrm{l}) & 0-76.0 \\ \mathrm{NO}_{2}(\mu \mathrm{g} / \mathrm{l}) & 0-129.9 \\ \mathrm{PO}_{4}(\mu \mathrm{g} / \mathrm{l}) & 0.8-42.5 \\ \mathrm{Si}(\mu \mathrm{g} / \mathrm{l}) & 65.9-1467.5 \\ \mathrm{P}_{\text {tot }}(\mu \mathrm{g} / \mathrm{l}) & 20.2-56.9 \\ \mathrm{~N}_{\text {tot }}(\mu \mathrm{g} / \mathrm{l}) & 270.2-722.7\end{array}$

(1966; see tables 16-17): for example, they found 2-82 individuals / $\mathrm{m}^{2}$ of $C$. plumosus sensu Palmén \& Aho alone in different sites of the Bay of Brännskär in 1962 and up to 212 individuals / $\mathrm{m}^{2}$ near the buildings of the Biological Station in 1952. Moreover, according to a note book of Mrs. Laila Keynäs and part of her material preserved in the Finnish Museum of Natural History, Chironomus and Camptochironomusas were observed quite abundantly in the Bay of Brännskär in 1967. Chironomid studies in Tvärminne have not been carried out since then.

Palmén \& Aho (1966) carried out only salinity and temperature measurements from Tvärminne for their studies. Thus data on recent standard measurements of water chemistry (Table 2) cannot be used to suggest changes in water quality conditions. The current salinity is approximately the same as earlier.

For several years, one of the most common headlines in the public media has been the deterioration in the conditions found in the Baltic Sea water. Plant nutrients have contributed significantly to this phenomenon; as can be seen in Table 2, a hypertrophic situation prevailed in 1998 in the study area. To reduce the local pollution, water treatment facilities were built for the Biological Station in the late 1960's.

If there were subsequent changes in the chironomid assemblages, one may ask if they might be correlated to local amelioration or deterioration, to the pollution of the Baltic Sea, or to changes in toxicity of the Baltic Sea water. However, the amount of plant nutrients (Table 2) is not 
high compared to some other biotopes in Finland where members of the morphological C. plumosus sibling species aggregate occur. Some examples are given below.

Among the populations disussed in Michailova (2001:105; sub C. plumosus), the larvae living in the brackish water (salinity $<1 \%$ ) in the Vanhankaupunginlahti bay, Helsinki tolerated much higher concentrations of phosphorus and nitrogen than what was found in the sea water in Tvärminne: for example, $\mathrm{P}_{\text {tot }} 180 \mu \mathrm{g} / 1, \mathrm{~N}_{\text {tot }} 3,700$ $\mu \mathrm{g} / 1$ (Pesonen 1988).

Chironomus entis Shobanov, C. pr. plumosus Linnaeus, and especially many other species of the genus Chironomus coexist in the fresh water of Lokka Reservoir, Sodankylä, northern Finland. There, the nutrient levels were roughly at the same level as in Tvärminne in 1998 (cf. Table 2): $\mathrm{P}_{\text {tot }} 30-40 \mu \mathrm{g} / \mathrm{l}$ and $\mathrm{N}_{\text {tot }} 600-800 \mu \mathrm{g} / \mathrm{l}$ (Lepistö \& Pietiläinen 1996, Itkonen 1996). The bottom consisted of inundated peat covered with loose mud (dy). During the 1980's and 1990's, this mud layer produced huge swarms on the shore line of the reservoir, in which chironomids were "singing" splendidly with variable flight-tones that varied with the species (Sotavalta 1947: 102).

Linnaeus (1745, 1751: "Hafs-mygg") and Thienemann (1936, 1954: "Haffchironomiden") observed huge mass occurrences of large chironomid species at the southern Baltic Sea. The present situation at those areas would be worth studying, and sampling around Öland might even help the identification of the type specimens of $C$. plumosus. The "lacustrine species" occurs, as do numerous other freshwater species, in a low salinity along the shores. The pupa of the "marine species" discussed in the present paper is up to now known only from the brackish waters of Tvärminne. This cannot be the only suitable site for this supposed species in the Baltic Sea. The distance between Öland and Tvärminne is about $600 \mathrm{~km}$. Compared to Tvärminne area, the salinity near Öland is higher: $7 \%$ (Välikangas 1933) or even up to $8 \%$ (Järvekülg 1979).

Acknowledgements. The author thanks Prof. Dr. P. Michailova, Prof. Dr. V. Ilmari Pajunen and Mrs. Elina Hirvenoja, Mag. Phil., for field assistance, the anonymous referees, Dr. Martin Spies (Munich), the Amanuensis of the Tvärminne Biological Station Mrs. Laila Keynäs, Mag. Phil., and the librarian Mrs. Sirkka-Liisa Nyeki, Mag. Phil.

\section{Literature}

Åsberg, K. \& Stearn, W.T. 1973: Linnaeus's Öland and Gotland journey 1741. — Biol. J. Linn. Soc. 5: 1-107.

Goetghebuer, M. 1937-1954: Tendipedidae (Chironomidae). b) Subfamilie Tendipedinae (Chironominae). A. Die Imagines. - In: Lindner, E. (ed), Die Fliegen der palaearktischen Region 13c: 1-138.

Hirvenoja, M. 1998: Chironomus coaetaneus sp. n. (Diptera, Chironomidae) from the Lokka Reservoir, northern Finland. - Oulanka Reports 18: 53-61.

Itkonen, J. 1996: Lausunto Vuotoksen altaan veden laadunkehittymisestä sekä altaan vaikutuksesta Kemijoen, Kemijärven ja Perämeren tilaan. - Vuotoksen tekojärven ja voimalaitoksenrakentamista ja säännöstelyä koskevan vesioikeudellisen katselmustoimituksen katselmuskirjan liite 12 (Mimeograph). 127 pp.

Järvekülg, A. 1979: The bottom fauna of the eastern part of the Baltic Sea. Tallinn: Valgus. 382 pp. [In Russian.]

Keyl, H.G. \& Keyl, I. 1959: Die Cytologische Diagnostik der Chironomiden. I. Bestimmungstabelle für die Gattung Chironomus auf Grund der SpeicheldrüsenChromosomen. - Arch. F. Hydrobiol. 56: 43-57.

Kerkis. I.E., Kiknadze, I.I., Filippova, M., Shobanov, N., Gunderina, L. 1989: Cytogenetic differentation of the Chironomus species of the plumosus group. - Acta Biol. Debr. Oecol. Hung. 2: 103-114.

Langton, P.H. 1991: A key to pupal exuviae of West Palearctic Chironomidae. - Mimeograph. 386 pp.

Langton, P.H. 1995: A key to pupal exuviae of West Palearctic Chironomidae. Update on the genus Chironomus. - Mimeograph. 14 pp.

Lepistö, L. \& Pietiläinen, O-P. 1996: Kasviplanktonin määrän ja koostumuksen muutokset Lokassa, Porttipahdassa ja Kemijärvessä. (Changes in the quantity and composition of phytoplankton in two reservoirs, Lokka and Porttipahta and in Lake Kemijärvi.) Suomen Ympäristö 13: 1-73 + 5 appendages.

Linnaeus, C. 1745: Öländska och Gothländska Resa på Rikens Högloflige Ständers befallning förrättad Åhr 1741. — G. Kiesewetter, Stockholm och Uppsala. $(12)+344+(30)$ pp.

Linnaeus, C. 1746: Fauna suecica. — Stockholmie. 411 pp.

Linnaeus, C. 1758: Systema naturae per regna tria naturae. — Ed. 10, Vol. I, Holmiae. 1327 pp.

Michailova, P. 2001: Cytogenetic characteristics of species of the Chironomus plumosus group (Chironomidae, Diptera) in Finland. - Cytobios 105: 99-114.

Michailova, P. \& Mettinen, A. 2000: Cytotaxonomical variability of Chironomus plumosus L. and C. anthracinus Zett. (Diptera, Chironomidae) from industrial and municipal polluted areas of Finland. Caryologia 53: 69-81.

Palmén, E. 1955: Diel periodicity of pupal emergence in natural populations of some Chironomids. - Ann. Zool. Soc. Vanamo 17(3): 1-30.

Palmén, E. \& Aho, L. 1966: Studies on the ecology and phenology of the Chironomidae (Dipt.) of the North- 
ern Baltic. 2. Camptochironomus Kieff. and Chironomus Meig. - Ann. Zool. Fennici 3: 217-244.

Pedersen, B. V. 1988: Mechanisms underlying the stable co-existence of two genetically distinct populations of Chironomus plumosus (Diptera: Chironomidae) in Lake Tystrup-Bavelse, Denmark. - Holarctic Ecology 11: 106-110.

Pesonen, L. (ed.) 1988: Helsingin ja Espoon edustan merialueiden velvoitetarkkailu vuosina 1970-1986. - The City of Helsinki, Water and sewage works, Reports of the water conservation laboratory 17. [In Finnish.]

Shobanov, N. A. 1989: The morphological differentiation of Chironomus species of plumosus group (Diptera, Chironomidae). Larvae. - Acta Biol. Debr. Oecol. Hung. 2:335-344.

Shobanov, N. A. 2003: Morphological differentation of species of the Chironomus plumosus group (Diptera,
Chironomidae). Pupae. - Entomol. Obozrenie 82(2): 472-486.

Sotavalta, O. 1947: The flight-tone (wing stroke frequency) of insects. (Contributions to the problem of insect flight I.) — Acta Entomol. Fennica 4:1-117.

Strenzke, K. 1959: Revision der Gattung Chironomus Meig. I. Die Imagines von 15 norddeutschen Arten und Unterarten. -Arch. Hydrobiol. 56: 1-42.

Thienemann, A. 1936: Haffmücken und andere Salzwasser-Chironomiden. - Kieler Meeresforschungen 1:167-178.

Thienemann, A. 1954: Chironomus. Leben, Verbreitung und wirtschaftliche Bedeutung der Chironomiden. Binnengewässer 20:1-834.

Välikangas, I. 1933: Über die Biologie der Ostsee als Brackwassergebiet. — Verh. Int. Ver. Limnol. 6: 62112. 